\title{
Synthesis and Structure Elucidation for N-(2-pheny-4- thiazolidinone-3-yl)-2-(coumarin-4-yloxy)acetamide and Assessment Antibacterial Characteristics
}

\author{
Ahmed A. Al-Amiery 1,* (D) , Lina M. Shaker ${ }^{1}$, Tayser Sumer Gaaz ${ }^{2}$ (D) \\ Applied Science Department, University of Technology, Baghdad 10001, Iraq \\ Al-Mussaib Technical College, Al-Furat Al-Awsat Technical University, 51006, Babylon, Iraq \\ Correspondence: dr.ahmed1975@gmail.com;
}

Scopus Author ID 42060956400

Received: 1.11.2020; Revised: 30.11.2020; Accepted: 4.12.2020; Published: 10.12.2020

\begin{abstract}
Coumarins are structurally motivating molecules for synthesizing pharmaceutical agents such as anticancer, anticoagulants, and antimicrobial. The structure of the synthesized coumarin derivative (N-(2-pheny-4-thiazolidinone-3-yl)-2-(coumarin-4-yloxy)acetamide) was elucidated by spectroscopically techniques. The bacterial inhibition efficiency of N-(2-pheny-4-thiazolidinone-3-yl)2-(coumarin-4-yloxy)acetamide against selected types of bacteria, namely "Staphyloccocus aureus, as Gram-positive bacteria and Gram-negative bacteria Escherichia coli, Proteus vulgaris, Pseudomonas, and Klebsiella pneumoniae was determined utilizing a disc diffusion method. The scavenger effectiveness of the N-(2-pheny-4-thiazolidinone-3-yl)-2-(coumarin-4-yloxy)acetamide was also evaluated through the superoxide-radical method. The N-(2-pheny-4-thiazolidinone-3-yl)-2(coumarin-4-yloxy)acetamide has significant inhibitive efficiency against all studied microorganism. The N-(2-pheny-4-thiazolidinone-3-yl)-2-(coumarin-4-yloxy)acetamide molecules have considerable activity as antioxidant compounds against vitamin $\mathrm{C}$.
\end{abstract}

Keywords: anticoagulents; superoxide; coumarin; antimicrobial; microorganisim.

(C) 2020 by the authors. This article is an open-access article distributed under the terms and conditions of the Creative Commons Attribution (CC BY) license (https://creativecommons.org/licenses/by/4.0/).

\section{Introduction}

Coumarin derivatives, as natural and/or synthetic, have considerable interest due to their wide medicinal performances. Published studies demonstrate that coumarins are the most significant heterocyclic compounds with broad pharmacological activity spectra such as antitumor, anticoagulant, antimicrobial, scavengers, and anti-inflammatory [1-6]. The search for antibiotics has, for many years, created the field of intensive research in the field of drug chemistry due to the resistance that the microorganisms have created against known antibacterial or antifungal agents [6-9]. Antibacterial and antifungal agents are some of the most important factors in fighting microorganisms. It is known that bacteria and fungi cause infection and disease in humans [10]. Coumarins have a wide range of structural modifications [11-13] and can serve as molecular blocks for drug development. Coumarin derivatives are also considered potential antibacterial and antifungal agents, apart from antioxidants [14-17]. Continuing our investigations on the newly synthesized coumarin derivatives [18-41], we found it is interesting to synthesis a Schiff base compound derived from coumarin, namely " $\mathrm{N}$ (2-pheny-4-thiazolidinone-3-yl)-2-(coumarin-4-yloxy)acetamide" as an efficient antimicrobial 
agent. The scavenging activity of the newly synthesized compound was evaluated using the superoxide-radical technique.

\section{Materials and Methods}

\subsection{General.}

Starting materials and solvents were purchased from Merck and Fluka. No further purifications for the purchased chemicals. Fourier-transform infrared (FTIR) spectra were conducted by Spectrophotometer-8300 Shimadzu-FTIR. UV-Vis spectra were performed on spectrophotometer-160A Shimadzu-UV-VIS. Nuclear Magnetic Resonance (NMR) spectra were performed on Bruker-spectrometer-DPX 300MHz.Tetramethylsilane (YMS) was used as an internal standard. Carbon/Hydrogen/Nitrogen analyzers (CHN analysis) was achieved on a Carlo CHN-5500, Erba analyzer.

\subsection{Synthesis of N-(2-pheny-4-thiazolidinone-3-yl)-2-(coumarin-4-yloxy)acetamide.}

A dry benzene solution which has equimolar quantities of $N^{\prime}$-benzylidene-2-coumarin4-oxyacetohydrazide and 2-mercaptoethanoic acid was refluxed for $20 \mathrm{~h}$. Water was used to wash the filtered yield. The dichloromethane was used to recrystallized the dried product. Yield 70 percentage and the melting point was 261.0 celsius; Proton-Nuclear magnetic resonance spectroscopy (Chloroform-d): $\delta 7.320, \delta 7.441, \delta 7.92(\mathrm{~s}, 1 \mathrm{H})$ for aromatic protons; $\delta 5.82$ and $4.77(\mathrm{~s}, 1 \mathrm{H})$ for vinyl proton; $\delta 5.110(\mathrm{~s}, 2 \mathrm{H})$ for methylene oxide proton; $\delta 8.98(\mathrm{~s}, 1 \mathrm{H})$ for amino proton, $\delta 5.40(\mathrm{~s}, 1 \mathrm{H})$ for $\mathrm{S}-\mathrm{CH}$, and $\delta 3.832(\mathrm{H})$ for methylene protons, $\delta(\mathrm{s}, 2 \mathrm{H}) .{ }^{13} \mathrm{C}$ Nuclear magnetic resonance spectroscopy: 33.2, 65.4, 77.6, 101.4, 110.1, 112.9, 114.4, 117.1, $120.1,124.3,126.1,127.8,128.2,159.8,154.1,167.8,169.0$ and 171. Fourier-transform is infrared in $\mathrm{cm}^{-1}$ : 1689 and 1667 for carbonyl of the amide group, 1731 carbonyl of lactone group, 2921 aliphatic hydrogen, 3087.7 aromatic hydrogens, 3198.7 amino group, 1632.8 $\mathrm{cm}^{-1}$ (aromatic carbon-carbon bonds; Calculated/ Theoretical CHN analysis for $\mathrm{C}_{20} \mathrm{H}_{16} \mathrm{~N}_{2} \mathrm{O}_{5} \mathrm{~S}$ : C 60.41/60.60\%, H 3.91/4.07\%, N 6.88/7.07\%.

\subsection{Antibacterial activity.}

The synthesized compound N-(2-pheny-4-thiazolidinone-3-yl)-2-(coumarin-4yloxy)acetamide was screened in vitro for its antimicrobial efficiency against gram-positive bacteria (Staphylococcus aureus) and gram-negative bacteria (Escherichia coli, Proteus vulgaris, Klebsiella pneumoniae, and Pseudomonas aeruginosa) by disc diffusion techniques [42]. The method of disc diffusion was utilized due to its Comfortable, worth, and inexpensive. The N-(2-pheny-4-thiazolidinone-3-yl)-2-(coumarin-4-yloxy)acetamide in dimethylformamide as a stock solution has been prepared. The stock solution was diluted by dimethylformamide to prepare various concentrations $(50-500 \mu \mathrm{g} / \mathrm{ml})$. For each dilution, dimethylformamide was utilized as control. The nutrient agar was used for subcultured the bacteria. Chloramphenicol (positive control) was used as a standard antimicrobial drug and compared with the synthesized compound. Whatman filter papers (no. 4) discs of $6 \mathrm{~mm}$ diameter have been sterilized and immersed in the desired concentration of the N-(2-pheny-4thiazolidinone-3-yl)-2-(coumarin-4-yloxy)acetamide. The socked discs were placed in Petridishes, having the nutrient agar with the selected types of bacteria individually and incubated for $24 \mathrm{~h}$., at $37^{\circ} \mathrm{C}$. The antibacterial efficiencies were evaluated as mean $\pm \mathrm{SD}$. 


\subsection{Antioxidant activity.}

The antioxidant efficiency measurements were conducted by the superoxide anion technique, according to Chang 2002 [43]. Nitro blue tetrazolium solution (1 mL) which was prepared by dissolve Nitroblue tetrazolium in phosphate buffer and various concentrations (50, $100,150,200,300,500 \mu \mathrm{g} / \mathrm{ml})$ of $\mathrm{N}$-(2-pheny-4-thiazolidinone-3-yl)-2-(coumarin-4yloxy)acetamide. Added $100 \mu \mathrm{l}$ to the above solution. The incubation was conducted for $5 \mathrm{~min}$., at $25^{\circ} \mathrm{C}$, and the absorbance was measure at $560 \mathrm{~nm}$. The comparing of N-(2-pheny-4thiazolidinone-3-yl)-2-(coumarin-4-yloxy)acetamide has been done with the standard (vitamin C).

\subsection{Statistical analysis.}

ANOVA technique was used to evaluate the statistical analysis. $P<0.05$ was the significant value, and $P<0.001$ the excellent one.

\section{Results and Discussion}

\subsection{Chemistry.}

N'-benzylidene-2-coumarin-4-oxyacetohydrazide was refluxed with 2mercaptoethanoic acid to synthesis the target N-(2-pheny-4-thiazolidinone-3-yl)-2-(coumarin4-yloxy)acetamide as demonstrated in Figure 1. The spectrum of FTIR for the synthesized compound N-(2-pheny-4-thiazolidinone-3-yl)-2-(coumarin-4-yloxy)acetamide exhibited significant bands at 1689 and 1667 for carbonyl of amide group and 1731 carbonyl of lactone group. The NHM spectrum showed the singlate for single protons at $5.82 \mathrm{ppm}$ and $4.77 \mathrm{ppm}$ for the vinyl group and also siglate at $5.110 \mathrm{ppm}$ for two protons of methylene oxide group.

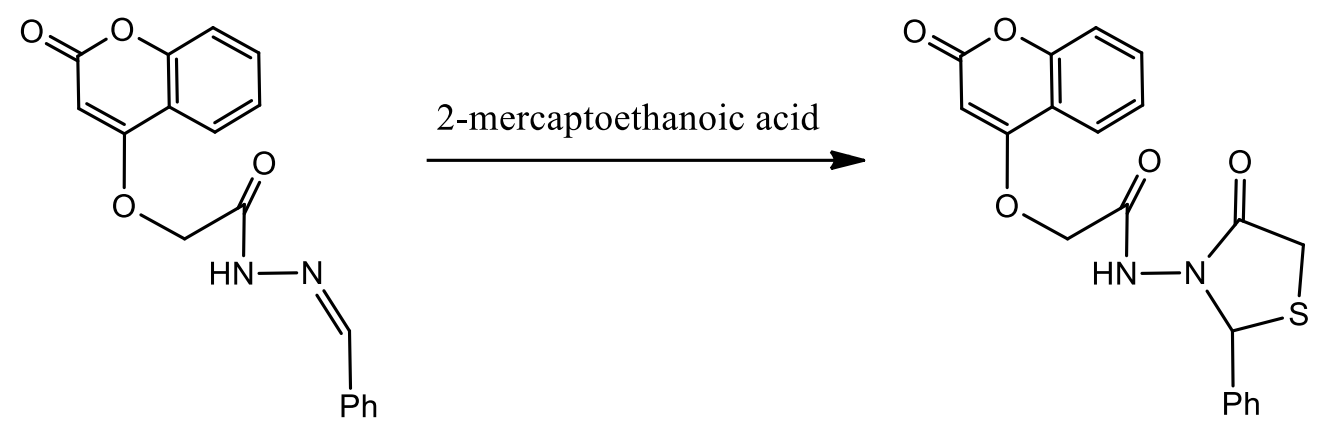

Figure 1. Synthesis of N-(2-pheny-4-thiazolidinone-3-yl)-2-(coumarin-4-yloxy)acetamide.

\subsection{Pharmacology: in vitro antibacterial studies.}

The results of the disk diffusion method are shown in Figure 2. The experiments were repeated three times, and the standard error was $\pm 0.1 \mathrm{~mm}$. Dimethylformamide was the negative control and the solvent for the $N$-(2-pheny-4-thiazolidinone-3-yl)-2-(coumarin-4yloxy)acetamide, which was used in this research, while chloramphenicol was the positive standard which was used in all the experiments. The results of these experiments reveal that $\mathrm{N}$ (2-pheny-4-thiazolidinone-3-yl)-2-(coumarin-4-yloxy)acetamide has significant efficiency against the human pathogenic tested gram-positive bacteria and human pathogenic tested gramnegative bacteria, as shown in Figure 2. 

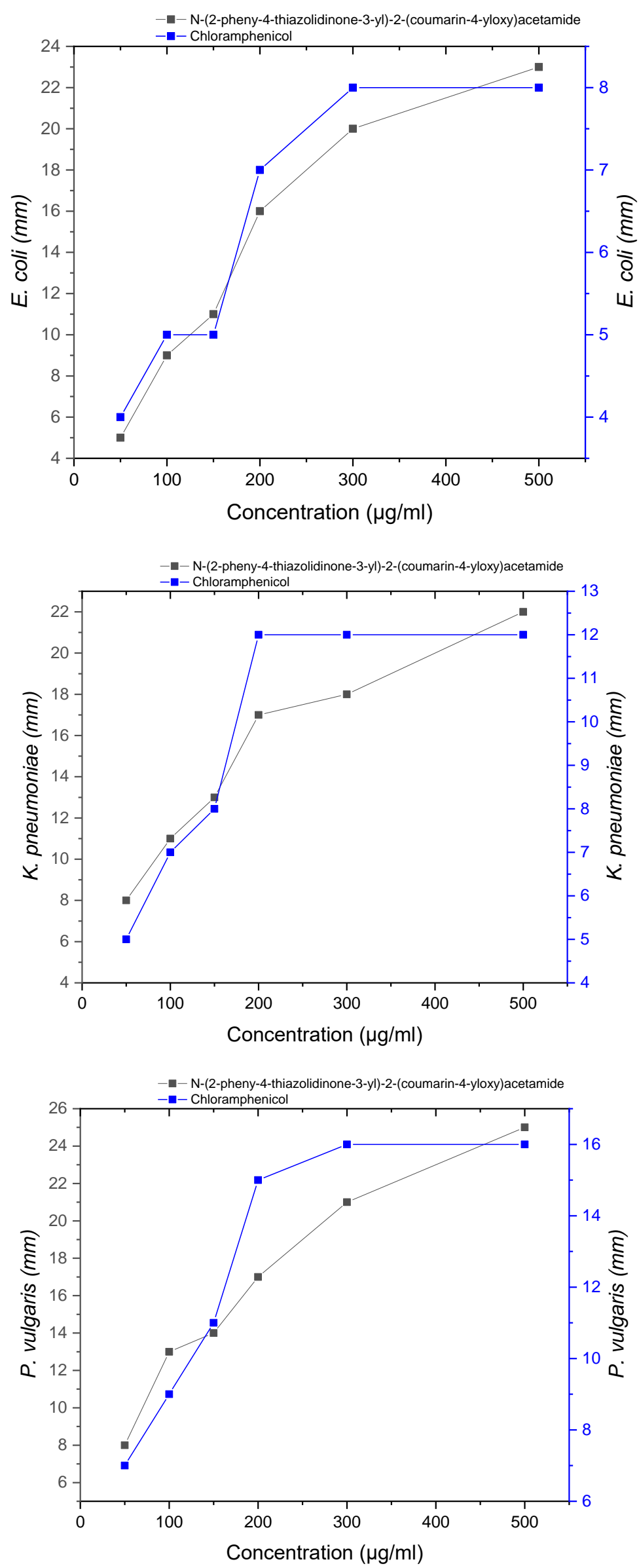

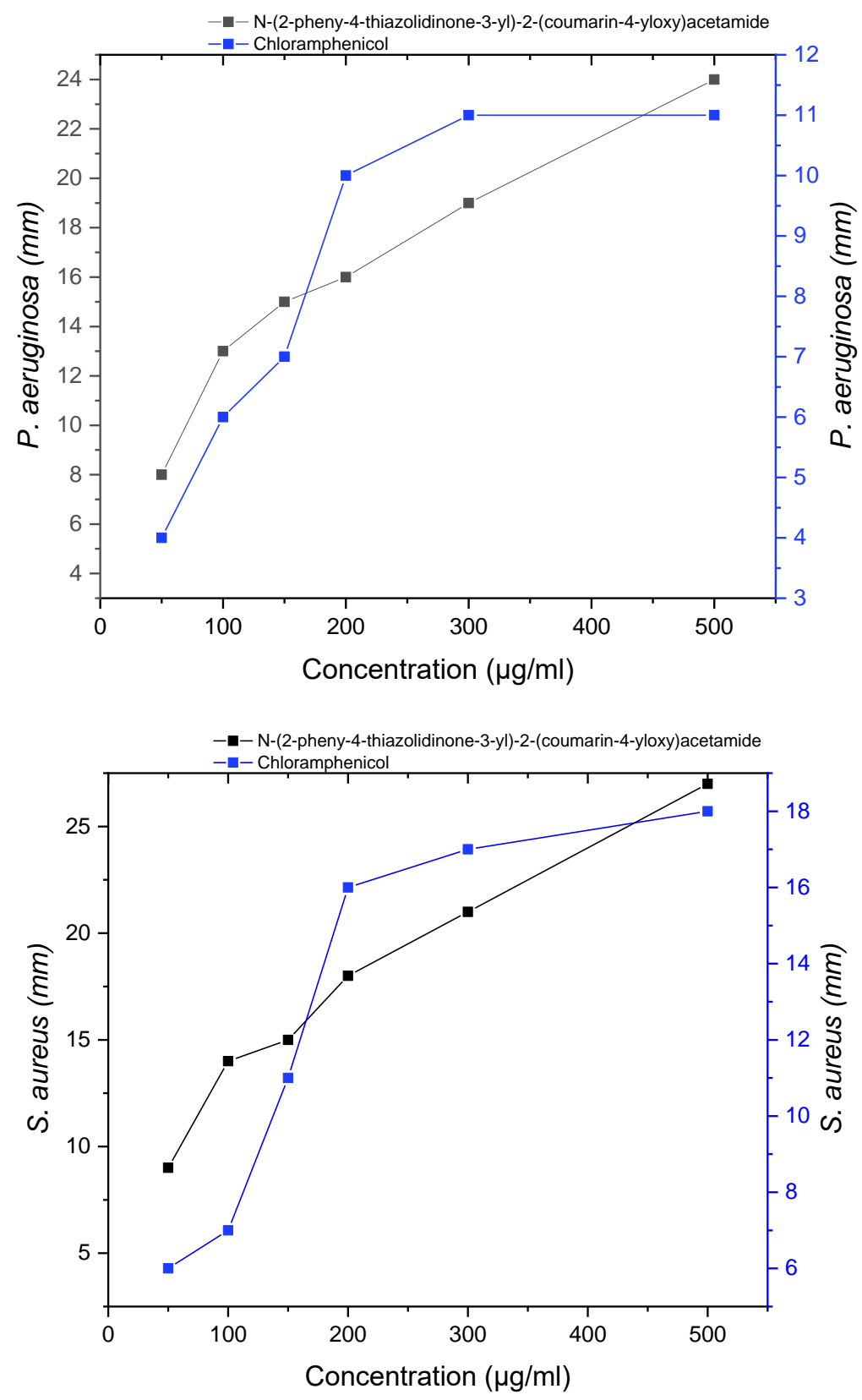

Figure 2. Antibacterial efficiencies of different concentrations N-(2-pheny-4-thiazolidinone-3-yl)-2-(coumarin4-yloxy)acetamide against chloramphenicol.

According to inhibition zone findings, the N-(2-pheny-4-thiazolidinone-3-yl)-2(coumarin-4-yloxy)acetamide demonstrates significant efficiency versus gram-positive Staphylococcus aureus than the efficiency against gram-negative. The efficiency has increased with an increase in the concentration of N-(2-pheny-4-thiazolidinone-3-yl)-2-(coumarin-4yloxy)acetamide.

The nitrogen atoms were correlated with an increased inhibition efficiency for Staphylococcus aureus. N-(2-pheny-4-thiazolidinone-3-yl) -2-(coumarin-4-yloxy) acetamide demonstrated significant antimicrobial performance against Proteus vulgaris. N-(2pheny-4-thiazolidinone-3-yl)-2-(coumarin-4-yloxy)acetamide as the investigated compound was a lower efficiency than the control chloramphenicol. 


\subsection{Antioxidant activity.}

There is a growing interest in scavengers, specifically in these supposed to prevent the presumed deleterious outcomes of free radicals in the human physique and to stop the deterioration of fats and other ingredients of food stuffs. In each case, there is a choice for scavengers from herbal rather than from synthetic sources. As expanded scavenger fame helps limit the oxidative damage and delays or prevents pathological changes, a viable antioxidant remedy has to be blanketed both as natural free-radical-scavenging antioxidant enzymes or as an agent that is successful in augmenting the recreation of scavenger enzymes [44].

Superoxide anion radical (O2-) is an important factor in the killing of bacteria- [45]. Indicating the superoxide exhaustion within the reaction mixtures. Figure 3 shows the inhibitive performance of superoxide radical using the concentrations 50,100, 150, 200, 300, $500 \mu \mathrm{g} / \mathrm{ml}$ of $\mathrm{N}$-(2-pheny-4-thiazolidinone-3-yl)-2-(coumarin-4-yloxy)acetamide compared with vitamin $\mathrm{C}$. The concentration of the $\mathrm{N}$-(2-pheny-4-thiazolidinone-3-yl)-2-(coumarin-4yloxy)acetamide has a significant level $(\mathrm{P}<0.001)$ of superoxide radical antioxidant activity as compared with vitamin $\mathrm{C}$.

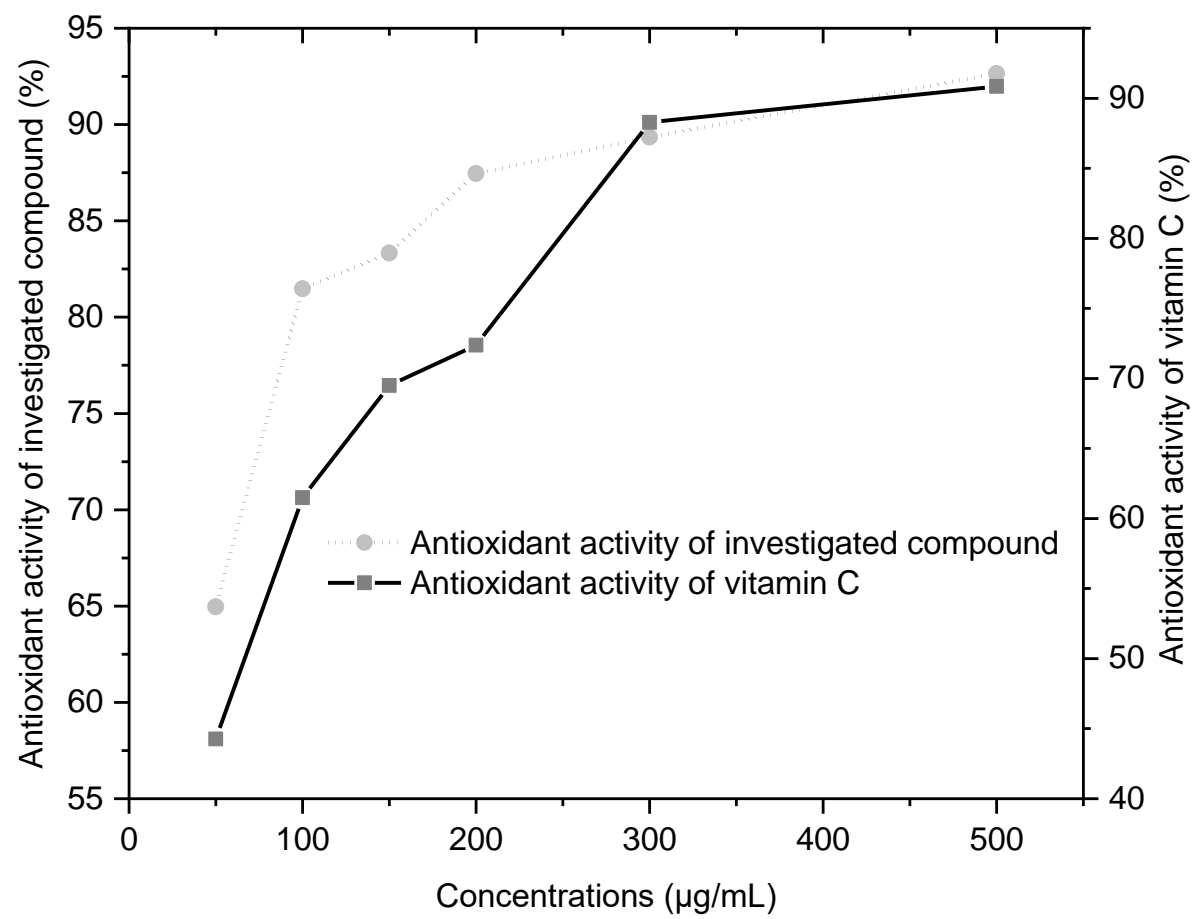

Figure 3. Scavenging efficiencies of different concentrations of $N$-(2-pheny-4-thiazolidinone-3-yl)-2-(coumarin4-yloxy)acetamide aginst vitamin $\mathrm{C}$.

\section{Conclusions}

In conclusion, N-(2-pheny-4-thiazolidinone-3-yl)-2-(coumarin-4-yloxy)acetamide was synthesized by reacting coumarin-Schiff base with 2-mercaptoethanoic acid. The chemical structure of N-(2-pheny-4-thiazolidinone-3-yl)-2-(coumarin-4-yloxy)acetamide was confirmed by various spectroscopic techniques, and the antimicrobial and antioxidant activities were assessed. N-(2-pheny-4-thiazolidinone-3-yl)-2-(coumarin-4-yloxy)acetamide was examined against a slected types of human pathogenic strains of Gram-positive (Staphyloccocus aureus) and Gram-negative (E. coli, Proteus vulgaris, Pseudomonas, and Klebsiella pneumoniae) bacteria. N-(2-pheny-4-thiazolidinone-3-yl)-2-(coumarin-4yloxy)acetamide a significant growth inhibition efficient against selected types of bacteria and 
is promising to act as a considerable antibacterial agent as compared with chloramphenicol. Antioxidant results also revealed that N-(2-pheny-4-thiazolidinone-3-yl)-2-(coumarin-4yloxy)acetamide demonstrates significant efficiency against superoxide.

\section{Funding}

This research received no external funding.

\section{Acknowledgments}

The authors are grateful to the University of Technology/ Baghdad-Iraq for support.

\section{Conflicts of Interest}

The authors declare no conflict of interest.

\section{References}

1. Koleva, A.; Yankova, N.; Nikolova, R. Synthesis and Chemical Properties of 3-Phosphono-coumarins and 1,2-Benzoxaphosphorins as Precursors for Bioactive Compounds. Molecules 2019, 24, https://doi.org/10.3390/molecules24112030.

2. Foroozesh, M.; Sridhar, J.; Goyal, N.; Liu, J. Coumarins and P450s, Studies Reported to-Date. Molecules 2019, 24, https://doi.org/10.3390/molecules24081620.

3. Bruni, R.; Barreca, D.; Protti, M.; Brighenti, V.; Righetti, L.; Anceschi, L.; Mercolini, L.; Benvenuti, S.; Gattuso, G.; Pellati, F. Botanical Sources, Chemistry, Analysis, and Biological Activity of Furanocoumarins of Pharmaceutical Interest. Molecules 2019, 24, https://doi.org/10.3390/molecules24112163.

4. Hanoon, M.; Resen, A.; Shaker, L.; Kadhum, A.; Al-Amiery, A. Corrosion Investigation of Mild Steel in Aqueous Hydrochloric Acid Environment Using N-(Naphthalen-1-yl)-1-(4-Pyridinyl)Methanimine Complemented with Antibacterial Studies. Biointerface Research in Applied Chemistry 2021, 11, 97359743, https://doi.org/10.33263/BRIAC112.97359743.

5. Ozaki, Y.; Ohashi, T.; Niwa, Y. A comparative study on the effects of inhibitors of the lipoxygenase pathway on neutrophil function. Inhibitory effects on neutrophil function may not be attributed to inhibition of the lipoxygenase pathway. Biochem. Pharmacol. 1986, 35, https://doi.org/10.1016/0006-2952(86)90615-5.

6. Al-Amiery, A.; Shaker, L.; Gaaz, T. Hydroxycoumarin Grafted with Hydrazine: Synthesis, Structure Elucidation and Assessment of Antioxidant and Antibacterial Characteristics. Biointerface Research in Applied Chemistry 2021, 11, 10393-10401.

7. Da Re, P.; Bonola, G.; Verlicchi, L. A series of Coumarin Derivatives with Central Stimulating Activity. $J$. Med. Chem. 1964, 7, 162-166, https://doi.org/10.1021/jm00332a010.

8. Hussain, A.; AlAjmi, M.F.; Rehman, M.T.; Amir, S.; Husain, F.M.; Alsalme, A.; Siddiqui, M.A.; AlKhedhairy, A.A.; Khan, R.A. Copper(II) complexes as potential anticancer and Nonsteroidal antiinflammatory agents: In vitro and in vivo studies. Sci. Rep. 2019, 9, https://doi.org/10.1038/s41598-01941063-X.

9. Liao, Y.; Zhao, J.; Bulek, K.; Tang, F.; Chen, X.; Cai, G.; Jia, S.; Fox, P.; Huang, E.; Pizarro, T.; Kalady, M.F.; Jackson, M.W.; Bao, S.; Sen, G.C.; Stark, G.R.; Chang, C.J.; Li, X. Inflammation mobilizes copper metabolism to promote colon tumorigenesis via an IL-17-STEAP4-XIAP axis. Nat. Commun. 2020, 11, https://doi.org/10.1038/s41467-020-14698-y.

10. Sukul, A.; Poddar, S.K.; Haque, S.; Kumar, S.; Das, S.; Mahmud, Z.; Rahman, A. Synthesis, Characterization and Comparison of Local Analgesic, Anti-Inflammatory, Anti-Ulcerogenic Activity of Copper and Zinc Complexes of Indomethacin. Anti-Inflamm. Anti-Allergy Agents Med. Chem. 2017, 15, 221-233, https://doi.org/10.2174/1871523016666170217103402.

11. Selvi, G.; Özdemir, F.A.; Aykutoglu, G.; Özdemir, N.; Şerbetçi, Z.; Çetinkaya, B.; Dayan, O. A neutral arene ruthenium(II) complex with a sulfonated N,O-chelating ligand: Synthesis, characterization, in vitro cytotoxicity and antibacterial activity. Polyhedron 2020, 176, https://doi.org/10.1016/j.poly.2019.114300.

12. Abd-Allah, W.H.; Osman, E.E.A.; Anwar, M.A.-E.-M.; Attia, H.N.; El Moghazy, S.M. Design, synthesis and docking studies of novel benzopyrone derivatives as anticonvulsants. Bioorganic Chemistry 2020, 98, https://doi.org/10.1016/j.bioorg.2020.103738.

13. Cai, G.; Yu, W.; Song, D.; Zhang, W.; Guo, J.; Zhu, J.; Ren, Y.; Kong, L. Discovery of fluorescent coumarinbenzo[b]thiophene 1, 1-dioxide conjugates as mitochondria-targeting antitumor STAT3 inhibitors. European Journal of Medicinal Chemistry 2019, 174, 236-251, https://doi.org/10.1016/j.ejmech.2019.04.024. 
14. Amr, A. .-G.; Mageid, R.E.A.; El-Naggar, M.; M. Naglah, A.; S. Nossier, E.; Elsayed, E.A. Chiral Pyridine3,5-bis- (L-phenylalaninyl-L-leucinyl) Schiff Base Peptides as Potential Anticancer Agents: Design, Synthesis, and Molecular Docking Studies Targeting Lactate Dehydrogenase-A. Molecules 2020, 25, https://doi.org/10.3390/molecules25051096.

15. Warad, I.; Ali, O.; Al Ali, A.; Jaradat, N.A.; Hussein, F.; Abdallah, L.; Al-Zaqri, N.; Alsalme, A.; Alharthi, F.A. Synthesis and Spectral Identification of Three Schiff Bases with a 2-(Piperazin-1-yl)-N-(thiophen-2-yl methylene)ethanamine Moiety Acting as Novel Pancreatic Lipase Inhibitors: Thermal, DFT, Antioxidant, Antibacterial, and Molecular Docking Investigations. Molecules 2020, 25, https://doi.org/10.3390/molecules25092253.

16. Mirza, Z.; Soto, E.R.; Hu, Y.; Nguyen, T.-T.; Koch, D.; Aroian, R.V.; Ostroff, G.R. Anthelmintic Activity of Yeast Particle-Encapsulated Terpenes. Molecules 2020, 25, https://doi.org/10.3390/molecules25132958.

17. Annunziata, F.; Pinna, C.; Dallavalle, S.; Tamborini, L.; Pinto, A. An Overview of Coumarin as a Versatile and Readily Accessible Scaffold with Broad-Ranging Biological Activities. International Journal of Molecular Sciences 2020, 21, https://doi.org/10.3390/ijms21134618.

18. Zinad, D.; Hanoon, M.; Dawood, R.; Ibrahim, S.; Al-Amiery, A.; Takriff, M.; Kadhum, A. A new synthesized coumarin-derived Schiff base as a corrosion inhibitor of mild steel surface in $\mathrm{HCl}$ medium: gravimetric and DFT studies. International Journal of Corrosion and Scale Inhibition 2020, 9, 228-243, https://doi.org/10.17675/2305-6894-2020-9-1-14.

19. Zinad, D.; Jawad, Q.; Mahmood, M.; Mahal, A.; Mohamed, 1.; Al-Amiery, A. Adsorption, temperature and corrosion inhibition studies of a coumarin derivatives corrosion inhibitor for mild steel in acidic medium: gravimetric and theoretical investigations. Int. J. Corros. Scale Inhib. 2020, 9, 134-151, https://doi.org/10.17675/2305-6894-2020-9-1-8.

20. AL-Duhaidahawi, D.L.; Al-Majedy, Y.K.; Ibraheem, H.H.; Kadhum, A.A.H.; Al-Amiery, A.A. Macro coumarins as novel antioxidants. Oriental Journal of Chemistry 2018, 34, 2562-2569, http://dx.doi.org/10.13005/ojc/340544.

21. Al-Azawi, K.F.; Al-Baghdadi, S.B.; Mohamed, A.Z.; Al-Amiery, A.A.; Abed, T.K.; Mohammed, S.A.; Kadhum, A.A.H.; Mohamad, A.B. Synthesis, inhibition effects and quantum chemical studies of a novel coumarin derivative on the corrosion of mild steel in a hydrochloric acid solution. Chemistry Central Journal 2016, 10, https://doi.org/10.1186/s13065-016-0170-3.

22. Al-Amiery, A.A.; Al-Majedy, Y.K.; Kadhum, A.A.H.; Mohamad, A.B. Synthesis of new coumarins complemented by quantum chemical studies. Research on Chemical Intermediates 2016, 42, 3905-3918, https://doi.org/10.1007/s11164-015-2252-6.

23. Al-Majedy, Y.K.; Al-Duhaidahawi, D.L.; Al-Azawi, K.F.; Al-Amiery, A.A.; Kadhum, A.A.H.; Mohamad, A.B. Coumarins as potential antioxidant agents complemented with suggested mechanisms and approved by molecular modeling studies. Molecules 2016, 21, https://doi.org/10.3390/molecules21020135.

24. Al-Majedy, Y.K.; Kadhum, A.A.H.; Al-Amiery, A.A.; Mohamad, A.B. Coumarins: The antimicrobial agents. Systematic Reviews in Pharmacy 2016, 8, 62-70.

25. Al-Majedy, Y.; Al-Amiery, A.; Kadhum, A.A.; Bakar Mohamad, A. Antioxidant activity of coumarins. Systematic Reviews in Pharmacy 2016, 8, 24-30.

26. Issa, A.Y.; Rida, K.S.; Salam, A.Q.; Al-Amiery, A.A. Acetamidocoumarin as a based eco-friendly corrosion inhibitor. International Journal of ChemTech Research 2016, 9, 39-47.

27. Al-Amiery, A.A.; Al-Majedy, Y.K.; Kadhum, A.A.H.; Mohamad, A.B. Hydrogen peroxide scavenging activity of novel coumarins synthesized using different approaches. PLoS ONE 2015, 10, https://doi.org/10.1371/journal.pone.0132175.

28. Al-Amiery, A.A.; Al-Majedy, Y.K.; Kadhum, A.A.H.; Mohamad, A.B. Novel macromolecules derived from coumarin: Synthesis and antioxidant activity. Scientific Reports 2015, 5, https://doi.org/10.1038/srep11825.

29. Al-Amiery, A.A.; Musa, A.Y.; Kadhum, A.A.H.; Mohamad, A.B. The Use of Umbelliferone in the Synthesis of New Heterocyclic Compounds. Molecules 2011, 16, 6833-6843, https://doi.org/10.3390/molecules16086833.

30. Al-Amiery, A.A.; Al-Majedy, Y.K.; Kadhum, A.A.H.; Mohamad, A.B. New Coumarin Derivative as an Eco-Friendly Inhibitor of Corrosion of Mild Steel in Acid Medium. Molecules 2015, 20, 366-383, https://doi.org/10.3390/molecules20010366.

31. Al-Majedy, Y.K.; Kadhum, A.A.H.; Al-Amiery, A.A.; Mohamad, A.B. Synthesis and characterization of some new 4-hydroxycoumarin derivatives. Molecules 2014, 19, 11791-11799, https://doi.org/10.3390/molecules190811791.

32. Kadhum, A.A.H.; Mohamad, A.B.; Hammed, L.A.; Al-Amiery, A.A.; San, N.H.; Musa, A.Y. Inhibition of Mild Steel Corrosion in Hydrochloric Acid Solution by New Coumarin. Materials 2014, 7, 4335-4348, https://doi.org/10.3390/ma7064335.

33. Mohamad, A.B.; Kadhum, A.A.H.; Al-Amiery, A.A.; Ying, L.C.; Musa, A.Y. Synergistic of a coumarin derivative with potassium iodide on the corrosion inhibition of aluminum alloy in $1.0 \mathrm{M} \mathrm{H} 2 \mathrm{SO}$. Metals and Materials International 2014, 20, 459-467, https://doi.org/10.1007/s12540-014-3008-3. 
34. Kadhum, A.A.H.; Mohamad, A.B.; Hammed, L.A.; Al-Amiery, A.A.; San, N.H.; Musa, A.Y. Inhibition of mild steel corrosion in hydrochloric acid solution by new coumarin. Materials 2014, 7, 4335-4348, https://doi.org/10.3390/ma7064335.

35. Mohamad, A.B.; Kadhum, A.A.H.; Al-Amiery, A.A.; Ying, L.C.; Musa, A.Y. Synergistic of a coumarin derivative with potassium iodide on the corrosion inhibition of aluminum alloy in 1.0 M H2SO4. Metals and Materials International 2014, 20, 459-467, https://doi.org/10.1007/s12540-014-3008-3.

36. Al-Amiery, A.A.; Kadhum, A.A.H.; Al-Majedy, Y.K.; Ibraheem, H.H.; Al-Temimi, A.A.; Al-Bayati, R.I.; Mohamad, A.B. The legend of 4-aminocoumarin: Use of the Delépine reaction for synthesis of 4iminocoumarin. Research on Chemical Intermediates 2013, 39, 1385-1391, https://doi.org/10.1007/s11164012-0694-7.

37. Al-Amiery, A.A.; Al-Bayati, R.I.H.; Saour, K.Y.; Radi, M.F. Cytotoxicity, antioxidant, and antimicrobial activities of novel 2-quinolone derivatives derived from coumarin. Research on Chemical Intermediates 2012, 38, 559-569, https://doi.org/10.1007/s11164-011-0371-2.

38. Al-Amiery, A.A.; Kadhum, A.A.H.; Mohamad, A.B. Antifungal activities of new coumarins. Molecules 2012, 17, 5713-5723, https://doi.org/10.3390/molecules17055713.

39. Al-Amiery, A.A.; Jaffar, H.D.; Obayes, H.R.; Musa, A.Y.; Kadhum, A.A.H.; Mohamad, A.B. Thermodynamic studies on 4-aminocoumarin tautomers. International Journal of Electrochemical Science 2012, 7, 8468-8472.

40. Kadhum, A.A.H.; Al-Amiery, A.A.; Musa, A.Y.; Mohamad, A.B. The antioxidant activity of new coumarin derivatives. International Journal of Molecular Sciences 2011, 12, 5747-5761, https://doi.org/10.3390/ijms12095747.

41. Kadhum, A.A.H.; Mohamad, A.B.; Al-Amiery, A.A.; Takriff, M.S. Antimicrobial and antioxidant activities of new metal complexes derived from 3-aminocoumarin. Molecules 2011, 16, 6969-6984, https://doi.org/10.3390/molecules16086969.

42. Al-Amiery, A.; Al-Majedy, Y.; Abdulreazak, H.; Abood, H. Synthesis, Characterization, Theoretical Crystal Structure, and Antibacterial Activities of Some Transition Metal Complexes of the Thiosemicarbazone (Z)2-(pyrrolidin-2-ylidene)hydrazinecarbothioamide. Bioinorganic Chemistry and Applications 2011, 2011, https://doi.org/10.1155/2011/483101.

43. Fernández-Bedmar, Z.; Demyda-Peyrás, S.; Merinas-Amo, T.; Del Río-Celestino, M. Nutraceutic potential of two allium species and their distinctive organosulfur compounds: A multi-assay evaluation. Foods 2019 , 8, https://doi.org/10.3390/foods8060222.

44. Aires, V.; Labbé, J.; Deckert, V.; Pais de Barros, J.-P.; Boidot, R.; Haumont, M.; Maquart, G.; Le Guern, N.; Masson, D.; Prost-Camus, E.; Prost, M.; Lagrost, L. Healthy adiposity and extended lifespan in obese mice fed a diet supplemented with a polyphenol-rich plant extract. Scientific Reports 2019, 9, https://doi.org/10.1038/s41598-019-45600-6.

45. Souza-Monteiro, J.; Arrifano, G.; Gois, I.; Mello, B.; Custódio, C.; Macedo, D.; Hamoy, M.; Paraense, R.; Bittencourt, L.; Lima, R.; Burbano, R.; Rogez, H.; Maia, C.; Macchi, B.; Nascimento, J.; Crespo-López, M. Antidepressant and Antiaging Effects of Açaí ( Euterpe oleracea Mart.) in Mice. Oxidative Medicine and Cellular Longevity 2019, 2019, 1-16, https://doi.org/10.1155/2019/3614960. 